\title{
Screening for PVYN-Wi Resistance in Kenyan Potato Cultivars
}

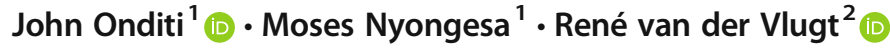

Received: 17 February 2020 / Accepted: 19 November 2020/ Published online: 8 January 2021

(C) The Author(s) 2021

\begin{abstract}
Over the past decades, two new strains of potato virus Y (PVYN-Wi(Wilga) and PVY ${ }^{\mathrm{NTN}}$ ) have been the most widely distributed worldwide in potato crops (Solanum tuberosum L.). Effective resistance genes comprehensive against all the known strains of the virus are available in some commercial cultivars. However, not all resistance genes in cultivars have been challenged by the new PVY strains to confirm effectiveness of the resistances available. This study was set to identify PVY resistant genotypes and estimate yield losses in potato cultivars in Kenya. PVYN-Wi was used for PVY resistance screening because it was the most prevalent strain in Kenya and also was found to produce more severe infection in Kenyan potato genotypes compared with $\mathrm{PVYO}^{\mathrm{O}}$ (the second most prevalent strain). Three cultivars, Kenya Karibu, Sherekea and Unica, were identified as resistant because they did not get PVY infections over three seasons of both greenhouse and field screening experiments. In addition, two early generation breeding clones were identified as resistant at 28 days post-inoculation. In susceptible cultivars Dutch Robyjn, Nyayo and Kenya Mpya, PVYN-Wi infection caused yield losses of 21.6, 39.0 and $53.1 \%$, respectively, after three seasons. This study demonstrated the necessity to screen for PVY resistance based on the most prevalent PVY strains and to make an informed decision on the usefulness of current levels of resistance in potato cultivars.
\end{abstract}

Keywords Potato virus $Y$. Screening for PVY resistance $\cdot$ Yield losses

René van der Vlugt

rene.vandervlugt@wur.nl

1 Kenya Agricultural and Livestock Research Organization, Horticultural Research Institute,

KALRO Tigoni, P.O. Box 338, Limuru 00217, Kenya

2 Laboratory of Virology, Wageningen University and Research, Droevendaalsesteeg 1, 6708 PB

Wageningen, The Netherlands 


\section{Introduction}

Potato (Solanum tuberosum L.) is the world's fourth most important food after wheat, rice and maize. The crop is grown in over 100 countries in all continents in the world (Birch et al. 2012). In Kenya, potato is the second most important food crop after maize because of its potential to provide food and nutrition security (MoALF 2016). Potato virus Y (PVY) is the most important virus of the potato crop and the fifth most important plant virus (German 2001; Scholthof et al. 2011). The virus, which is the type member of the genus Potyvirus and family Potyviridae (Adams et al. 2012) may cause yield losses of up to $80 \%$ in susceptible cultivars (Kopp et al. 2015). PVY is transmitted mainly from one cropping season to another through infected mother tubers to daughter tubers and by different species of aphids in a non-persistent manner (Quenouille et al. 2013). The virus can also be transmitted through mechanical contamination with infected plant tissues (Quenouille et al. 2013). Over the past three decades, the virus has been difficult to control mainly because of the rapid rate at which the virus has been undergoing genetic changes by recombination between the genomes of the two traditionally known strains $\mathrm{PVY}^{\mathrm{N}}$ and $\mathrm{PVYO}$ leading to the emergence of new strains (Kehoe and Jones 2016). As a result, prevalence of $\mathrm{PVY}^{\mathrm{N}}$ and $\mathrm{PVY} \mathrm{Y}^{\mathrm{O}}$ has been declining, while on the other hand, prevalence of over 10 newer PVY strains has been increasing. Of these PVYNTN (PVY-N Tuber Necrosis) and PVYN-Wi (PVY-N Wilga) are of most concern because they are the most widespread and cause yield losses in potato crop around the world (Crosslin et al. 2006; Lorenzen et al. 2006; Singh et al. 2008; Karasev and Gray 2013; Green et al. 2017).

An effective, economical, long-term and environmentally friendly option which has been successfully used to solve PVY problems is the use of resistant cultivars. PVY host resistance is either classified as extreme resistance (ER) or hypersensitive resistance (HR) (Solomon-Blackburn and Barker 2001). ER is effective against all the known strains of PVY (Quenouille et al. 2013). When a potato plant with ER is infected with PVY, the virus can replicate within the infected cell, but the cell gets killed quickly, effectively nearly eliminating cell-to-cell spread of the virus and thus its systemic spread throughout the plant. This ER results in very tiny necrotic spots or lesions which are often too small to be seen by eye. When such plants are tested using sensitive techniques, the virus is usually not detected in the plant though in some rare circumstances, extremely low amounts of the virus can be detected (Solomon-Blackburn and Barker 2001). ER genes $\left(R y_{c h o}, R y_{s t o}\right.$ and $\left.R y_{a d g}\right)$ for PVY resistance originally sourced from wild relatives of potato ( $S$. chacoense, S. stoloniferum and $S$. tuberosum ssp. andigena, respectively) are now available in many commercial cultivars around the world (Cockerham 1943; Munoz et al. 1975; Sato et al. 2006; Valkonen et al. 2017). HR genes on the other hand elicit hypersensitive reactions in potato cultivars upon infection with PVY. The virus can infect the plant but there is limited movement of the virus within the plant tissues. The plant also tries to kill its own cells in an attempt to stop systemic spread of the virus, sometimes resulting in visible necrotic spots on the leaves. The genes for HR ( $N y_{t b r}$ and $\left.N c_{t b r}\right)$ were sourced from $S$. sparsipilum and $S$. tuberosum, respectively, and have also been incorporated into commercial cultivars from the 1970s onwards (Jones 1990; Kerlan et al. 1999). Unlike ER, the HR genes are strain specific, meaning that cultivars with HR genes may be susceptible to new strains for which they do not have corresponding HR genes (i.e. $N y$ genes), but would still 
have resistance to older strains like PVYO and PVYC (Jones 1990; Kerlan et al. 1999). Considering the rapid spread of the new recombinant strains and the nature of available sources of PVY resistance, cultivars previously developed and screened against PVY may only have strain specific HR and need to be re-screened against new PVY strains in order to get effective sources of PVY resistance in potato cultivars.

In Kenya, PVY has been reported with high prevalence in farmers' fields (Gildemacher et al. 2009; Muthomi et al. 2011; Were et al. 2013; Nyamwamu et al. 2014), and this could be one of the main reasons for the low average tuber yields of $8.7 \mathrm{t} / \mathrm{ha}$ (FAOSTAT 2017), compared with over $35 \mathrm{t} / \mathrm{ha}$ which can be realized under experimental field potato growing conditions (Lung'aho et al. 2007; Onditi et al. 2012; NPCK 2017). The most widespread and destructive new recombinant PVY strains (PVYN-Wi and PVYNTN) have been reported in the country (Were et al. 2013) with PVYN-Wi found as the most prevalent PVY strain in a recent survey (Onditi 2020). There is however lack of information on whether there is PVYN-Wi resistance in the available potato germplasm collection in Kenya and whether the resistances available are effective in managing yield losses in major local cultivars. The option of PVY control using certified seed tubers in Kenya has not been successful because the quantity of certified potato seed available (5\%) is very low (NPCK 2017). This has forced farmers to replant their own saved seed tubers, a practice that may be contributing to further spread of the virus in the farmers' fields. In this situation, PVY-resistant cultivars can help in limiting spread of viruses through seed tubers over seasons in the cultivars grown by farmers. This study therefore (a) compares pathogenicity of PVYN-Wi against $\mathrm{PVY}$, (b) identifies effective sources of PVYN-Wi resistance within the Kenyan potato germplasm and (c) assesses the extent of yields losses caused by PVYN-Wi in the major potato cultivars.

\section{Materials and Methods}

\section{Potato Genotypes and PVY Strains for PVY Resistance Screening}

Potato genotypes used in this study included 12 potato cultivars (No. 1-12 in Table 1), obtained from the Kenya Agricultural and Livestock Research Organization (KALRO), Potato Research Centre based at Tigoni, Kenya and 16 potato clones obtained from the International Potato Center (CIP), Sub-Saharan Africa (SSA), Nairobi, Kenya. The 12 cultivars were selected because they are among the major potato cultivars grown in Kenya (NPCK 2017) and are also the main cultivars multiplied and distributed by the KALRO seed potato programme. The CIP clones (No. 13-28 in Table 1) were crosses between some of the major Kenyan cultivars and CIP parental lines with PVY resistance. The clones are at the early generation selection stage of breeding and have not previously been described with respect to their levels of PVY resistance.

All the above genotypes were obtained as in vitro plantlets from the potato tissue culture laboratory at KALRO, Potato Research Centre, Tigoni and were free of the six major potato viruses: Potato virus Y (PVY), Potato leaf roll virus (PLRV), Potato virus $X$ (PVX), Potato virus $M$ (PVM), Potato virus $A$ (PVA) and Potato virus $S$ (PVS) as tested by double antibody sandwich enzyme linked immune-sorbent assay (DAS- 
Table 1 Potato clones/cultivars used in the Potato virus Y (PVY) resistance screening experiments with their parental background, owner, year of official release in Kenya and previously described level of PVY resistance in different potato variety catalogues (NPCK 2017; CIP 2019)

\begin{tabular}{|c|c|c|c|c|c|}
\hline No. & Genotype & Parentage & Owner & Year of release & Resistance* \\
\hline 1 & Kenya Mpya & CIP 387170.16 x CIP 387170.9 & KALRO & 2010 & Unknown \\
\hline 2 & Dutch Robyjn & Rode Star x Preferent & KALRO & 1945 & $\mathrm{~S}$ \\
\hline 3 & Sherekea & CIP387231.7 x CIP387170.9 & KALRO & 2010 & HR \\
\hline 4 & Kenya Karibu & CIP 676064 x CIP 800946 & KALRO & 2005 & Unknown \\
\hline 5 & Asante & CIP378493.15 x BK Precoz & KALRO & 1998 & Unknown \\
\hline 6 & Tigoni & CIP378493.15 x BK Precoz & KALRO & 1998 & Susceptible \\
\hline 7 & Kenya Baraka & SDL.3680 e (18) x SDL.3070 d (4) & KALRO & 1973 & MR \\
\hline 8 & Kenya Mavuno & CIP 381378.18 x CIP 720084 & KALRO & 2002 & Unknown \\
\hline 9 & Unica & CIP387521.3 x Aphrodite & KALRO & 2017 & $\mathrm{R}$ \\
\hline 10 & Kerr's pink & Fortyfold x Smith's Early & KALRO & 1925 & $\mathrm{~S}$ \\
\hline 11 & Nyayo & Unknown & Unknown & Unknown & Unknown \\
\hline 12 & Shangi & Unknown & KALRO & 2015 & Unknown \\
\hline 13 & CIP312086.768 & CIP396311.1 x CIP398203.244 & CIP & Not released & Unknown \\
\hline 14 & CIP314923.69 & Tigoni x CIP398190.615 & CIP & Not released & Unknown \\
\hline 15 & CIP313010.19 & Desiree x CIP398190.735 & CIP & Not released & Unknown \\
\hline 16 & CIP313002.4 & Kenya Mpya x CIP388615.22UN & CIP & Not released & Unknown \\
\hline 17 & CIP313001.279 & Kenya Mpya x Shangi & CIP & Not released & Unknown \\
\hline 18 & CIP313039.199 & Tigoni x CIP397073.7 & CIP & Not released & Unknown \\
\hline 19 & CIP313009.84 & Asante x CIP397073.7 & CIP & Not released & Unknown \\
\hline 20 & CIP312084.731 & CIP392820.1 x CIP398208.219 & CIP & Not released & Unknown \\
\hline 21 & CIP313009.43 & Asante x CIP397073.7 & CIP & Not released & Unknown \\
\hline 22 & CIP314921.104 & Tigoni x CIP399002.52 & CIP & Not released & Unknown \\
\hline 23 & CIP313009.46 & Asante x CIP397073.7 & CIP & Not released & Unknown \\
\hline 24 & CIP314930.72 & Tacna x Meru Mugaruro & CIP & Not released & Unknown \\
\hline 25 & CIP314398.114 & Nyayo x B1C5024.53 & CIP & Not released & Unknown \\
\hline 26 & CIP313028.42 & Nyayo x CIP398201.510 & CIP & Not released & Unknown \\
\hline 27 & CIP312284.737 & LD-57.67 x CIP398208.219 & CIP & Not released & Unknown \\
\hline 28 & CIP313011.28 & Desiree x CIP398298.51 & CIP & Not released & Unknown \\
\hline
\end{tabular}

*Levels of resistance in the potato genotypes where $\mathrm{S}=$ susceptible, $\mathrm{MR}=$ moderate resistance, $\mathrm{HR}=$ hypersensitive resistance, $\mathrm{R}=$ resistant and Unknown = without any information on PVY resistance

ELISA). PVY strains for screening resistance were identified based on a survey of the PVY strains that occured in the five major potato growing areas in Kenya and where PVYN-Wi was the most prevalent PVY strain (Onditi 2020). PVYO, also identified from the above survey, was included in this study mainly to compare its ability to cause diseases in potato cultivars in relation to PVY ${ }^{\mathrm{N}-W i}$. The selected PVY strains were inoculated and maintained in tobacco plants (Nicotiana tabacum, cultivar White Burley) for use in the subsequent PVY resistance screening experiments. 


\section{Screen-House Inoculations of PVY in Resistance Screening}

In all screen-house experiments (described below), in vitro potato plantlets were raised in steam sterilized $\left(121^{\circ} \mathrm{C}\right.$ for $\left.15 \mathrm{~min}\right)$ soil in pots in an aphid-proof screen-house at KALRO, Tigoni, Kenya. The pots were $3 / 4$ filled with the soil mixed with $10 \mathrm{~g}$ of Di-Ammonium Phosphate (DAP-18-46-0) fertilizer. The plants were inoculated 2 weeks (4-6 leaf stage) after transplanting at a time when the plants had established. Tobacco leaves infected with the PVY strains (as described below in each experiment) were macerated in an ELISA extraction buffer (prepared as described in the ELISA procedure below) in the ratio of $1 \mathrm{~g}$ of leaf tissue to $2 \mathrm{ml}$ of the buffer. A small amount of Carborundum powder (300 mesh) was sprinkled on the leaves and $100 \mu \mathrm{l}$ of PVY inoculum was applied to the leaves of the plant and pressed gently on the leaf to spread the PVY inoculum. Water was applied to wash excess Carborundum from the leaves $5 \mathrm{~min}$ after inoculation. Sufficient moisture was maintained by daily irrigation throughout the cultivation period.

\section{Serological Detection of PVY in Resistance Screening}

All ELISA assays were done using the DAS-ELISA kit, antibodies and instructions as obtained from CIP, Lima, Peru. Wells of the ELISA plates (Thermo Scientific, Denmark) were loaded with $100 \mu \mathrm{l}$ of coating solution ( $35 \mu \mathrm{l}$ of PVY coating antiserum (PVY IgG) in $10 \mathrm{ml}$ of the coating buffer $\left(0.2 \mathrm{~g} \mathrm{Na}_{2} \mathrm{CO}_{3}, 0.44 \mathrm{~g} \mathrm{NaHCO}_{3}, 0.03 \mathrm{~g} \mathrm{NaN}_{2}\right.$ in $120 \mathrm{ml}$ of distilled water, $\mathrm{pH}$ 9.6)) and incubated overnight at $4{ }^{\circ} \mathrm{C}$. Washing of the plates was done using a buffer consisting of $8.0 \mathrm{~g} \mathrm{NaCl}, 0.2 \mathrm{~g} \mathrm{KH}_{2} \mathrm{PO}_{4}, 0.2 \mathrm{~g} \mathrm{KCL}, 1.13 \mathrm{~g} \mathrm{NaH}_{2} \mathrm{PO}_{4}, 0.29 \mathrm{~g}$ $\mathrm{NaN}_{2}$ and $0.05 \%$ of Tween 20 in $1 \mathrm{~L}$ of distilled water, pH 7.4 (PBS-T), with a 3 min soaking between the washes (procedure for all subsequent washings). Leaf material of $1 \mathrm{~g}$ was macerated in $2 \mathrm{ml}$ of ELISA extraction buffer (4.0 g PVP-40,000 and $2.0 \mathrm{~g}$ of egg ovalbumine in $200 \mathrm{ml}$ of PBS-T) and then $100 \mu \mathrm{l}$ samples were loaded into the wells in duplicates and incubated overnight at $4{ }^{\circ} \mathrm{C}$. Three positive controls consisting of potato leaf samples previously found infected with PVY in an ELISA test and 6 negative controls consisting of leaf samples found without PVY in the same test, were included. After washings, $100 \mu \mathrm{l}$ of conjugate solution (35 $\mu \mathrm{l}$ of PVY conjugate antiserum (PVY IgGAP) in $10 \mathrm{ml}$ of ELISA extraction buffer) was added to each well and incubated overnight at $4{ }^{\circ} \mathrm{C}$. Plates were washed and colour development was initiated by incubating the plates with $100 \mu \mathrm{l}$ per well of $15 \mathrm{mg}$ paranitrophenylphosphate (pNPP) in $20 \mathrm{ml}$ substrate buffer $(97 \mathrm{ml}$ diethanolamine in $1000 \mathrm{ml}$ distilled water, $\mathrm{pH}$ 9.8) at room temperature and incubating for $60 \mathrm{~min}$. Absorbance values of the samples were then taken at a wavelength $405 \mathrm{~nm}$ using an ELISA reader (Biotek ELX800, Vermont, USA). Positive samples were calculated as those with absorbance values equal or greater than the mean of the negative controls plus three times the standard deviation of the healthy controls. ELISA absorbance values were used to compare OD values in inoculated plants.

\section{Design of PVY Resistance Screening Experiments}

\section{Comparing Levels of Cultivar Resistance to PVYN-Wi in Relation to PVYO}

The experiment was arranged in a completely randomized design (CRD) in split plot. The main plots consisted of seven potato cultivars (Asante, Dutch Robyjn, Kenya 
Mpya, Sherekea, Kenya Karibu, Tigoni and Shangi from among the Kenyan cultivars in Table 1). The sub-plots were made up of two treatments (six plants of each cultivar inoculated with $\mathrm{PVYO}^{\mathrm{O}}$ and another six with $\mathrm{PVY}$-Wi) each in three replications. Inoculated and non-inoculated tobacco indicator plants of cultivar White Burley were included in each sub plot to confirm that the inoculum was infectious. The plants were maintained in the screen-house and at 28 days after inoculation (DAI), leaf samples were collected from the third leaf from the top from each of the six plants of each of the two treatments per sub-plot and tested in ELISA in two composites (three leaves each). The experiment was set to fit all samples in one ELISA plate with 96 wells (7 cultivars $\times 3$ replications each $\times 2$ treatments of $\mathrm{PVY}^{\mathrm{O}}$ and $\left.\mathrm{PVYN}-\mathrm{Wi}\right) \times 2$ composites tested per plot $=84$ wells). Data were collected on the type of symptoms observed and on the severity of symptoms, scored on a scale where $0=$ no symptoms, $1=$ very mild, $2=$ moderately mild, $3=$ moderate, $4=$ severe and $5=$ very severe.

\section{Screening for PVYN-Wi Resistance in a Screen-House over Three Seasons}

This experiment was conducted over three seasons of replanting tubers harvested from the previous season. The same experimental arrangement, management, data collection and ELISA tests were followed in all seasons. The experiment was arranged in a CRD design in split plots where the 12 Kenyan potato cultivars (No.1-12 in Table 1) were the main plots and the two sub-plots were PVYN-Wi inoculated plants of each cultivar and another set that were not inoculated. Each sub-plot (treatment) consisted of six plants in three replications. Leaf samples from each of the six plants per sub-plot were tested in ELISA in two composites (three leaves each) at 28 DAI. At this time, type of symptoms observed on sampled plants were recorded. Severity of symptoms were scored on a scale where $0=$ no symptoms, $1=$ very mild, $2=$ moderately mild, $3=$ moderate, $4=$ severe and $5=$ very severe. The plants were harvested at full maturity and data were collected on number and weight $(\mathrm{kg})$ of tubers per plant. Harvested tubers of each treatment of every cultivar were pooled together and randomly mixed. After sprouting, the tubers were planted for the second season experiment and similarly, tubers harvested from the second season were mixed randomly and were used to plant the third season experiment.

\section{Screening for PVYN-Wi Resistance in the Field over Three Seasons}

In vitro plantlets of the 12 local potato cultivars were all (30 plants per cultivar) inoculated with PVYN-Wi strain. The inoculated plants were maintained in the screenhouse and at harvest, at least 120 tubers were randomly picked from each lot of 12 cultivars, sprouted and used to plant the first season field experiment at KALRO Tigoni. Tubers harvested from each cultivar were thoroughly mixed and 120 tubers were selected randomly, sprouted and used to plant the second seasons trial and similarly tubers of the second season trial were used to plant a third season trial. Over the three seasons, the same experimental arrangement, management, data collection and ELISA tests were followed. The first season trial was conducted during long rains (April-July) 2017, the second season during short rains (September-November) 2017 and third season during long rains 2018. 
The trials were planted in Randomized Complete Block Designs (RCBD) in three replications with 40 plants per plot at a spacing of $0.77 \mathrm{~m} \times 0.3 \mathrm{~m}$ and each plot measured $3 \mathrm{~m} \times 3 \mathrm{~m}\left(9 \mathrm{~m}^{2}\right)$ with $1.0 \mathrm{~m}$ distance between the plots. The tubers were planted with 100 g per plant of Di-Ammonium Phosphate (DAP-18-46-0) fertilizer (Lung'aho et al. 2007). The crop was sprayed with insecticides to control virus vectors (aphids) and minimize virus transmission during the cropping period using locally recommended doses of insecticide, Marshal $250 \mathrm{EC} \circledR(50 \mathrm{ml} / 20 \mathrm{~L}$ of Carbosulfan $20 \%$ ) at 2-week intervals (or at every appearance of aphids). Late blight (Phytophthora infestans) infection in the crop was controlled using fungicides (Dithane M45®, wettable powder $80 \%$ mancozeb, $2.0 \mathrm{~g} / \mathrm{L}$ at emergence and Ridomil GOLDß, wettable powder $64 \%$ mancozeb, $4 \%$ metalaxyl, $2.5 \mathrm{~g} / \mathrm{L}$ ) at every appearance of the first symptoms. Weeding was done at emergence and was followed by earthing up just before flowering (Lung'aho et al. 2007). At 45 days after planting, eight plants from the middle rows of each plot were sampled (third leaf from the top) and tested in ELISA in two composites of four plants each. Type of symptoms observed in the sampled plants were recorded. Severity of symptoms were scored on a scale where $0=$ no symptoms, $1=$ very mild, $2=$ moderately mild, $3=$ moderate, $4=$ severe and $5=$ very severe. Harvesting was done at full maturity of the plants and data were collected on number and weight $(\mathrm{kg})$ of tubers per plant.

\section{Screening for PVYN-Wi Resistance in Early Generation Potato Clones}

Early generation potato clones (No.13-28 in Table 1) were arranged in CRD in three replications consisting of 6 plants per plot. All the plants were inoculated with PVYN-Wi strain and maintained in the screen-house for one season. In addition to the clones, cultivar Sherekea was used as a PVYN-Wi resistant control and similarly Dutch Robyjn and Kenya Mpya as susceptible controls. After inoculation, the plants were maintained in the screen-house until 28 DAI when leaf samples were collected from each of the six plants per plot (third leaf from the top). ELISA tests were conducted on all the six plants in two composites. Data were collected on the type of symptoms observed and on the severity of symptoms, scored on a scale where $0=$ no symptoms, $1=$ very mild, $2=$ moderately mild, $3=$ moderate, $4=$ severe and $5=$ very severe.

\section{Data Analysis}

All data collected on ELISA OD values and the number and weight of tubers from the experiments were subjected to analysis of variance (ANOVA) using Genstat software to generate means. The differences between the means were compared using least significant difference at LSD 0.05 (Steel and Torrie 1980). In the experiments on screening for PVYN-Wi resistance in the screen-house over three seasons, yield loss for every cultivar and for each season was calculated as the difference between the yields of the PVYN-Wi inoculated plants and their respective healthy controls. In the field screening experiment, yield in t/ha was calculated from the average weight of tubers harvested per plant per cultivar (i.e $1 \mathrm{ha}=44,400$ plants and $1 \mathrm{t}=1000 \mathrm{~kg}$ ). Yield loss was calculated as the percentage of the difference between the first and the third season trials. 


\section{Results}

\section{Comparing Levels of Cultivar Resistance to PVYN-Wi in Relation to PVYo}

Seven potato cultivars were inoculated in a screen-house sap inoculation experiment with PVYN-Wi and compared with the same set of cultivars inoculated with PVYO. All were compared in their ELISA OD values and type and severity of symptoms as summarized in Table 2. Cultivars Kenya Karibu and Sherekea were found not infected with either $\mathrm{PVY}^{\mathrm{O}}$ or $\mathrm{PVYN-Wi}$ at 28 DAI. These two cultivars did not develop symptoms both in $\mathrm{PVYO}$ and $\mathrm{PVY} \mathrm{N}^{\mathrm{N}-\mathrm{Wi}}$ inoculated plants.

Cultivar Shangi was infected with PVY ${ }^{\mathrm{N}-W i}$ but not PVYO based on the ELISA test. The cultivar did not show symptoms in both cases where it was inoculated with any of the two PVY strains. Similarly, Asante was also infected with PVY ${ }^{\mathrm{N}-W i}$ and not PVYO but only half of the samples tested positive. The rest of the cultivars, Tigoni, Dutch Robyjn and Kenya Mpya were all found to be infected by each of the two PVY strains. Among these three cultivars, the ELISA OD values were lowest in cultivar Tigoni followed by Dutch Robyjn and were highest in Kenya Mpya for each of the two PVY strains.

PVYN-Wi inoculated plants of cultivars Dutch Robyjn and Kenya Mpya showed significantly $(P \leq 0.05)$ higher ELISA OD values compared to those inoculated with $\mathrm{PVY}^{\mathrm{O}}$. There were also higher OD values in PVY ${ }^{\mathrm{N}-W \mathrm{i}}$ inoculated plants as compared to those inoculated with PVYO in cultivars Shangi, Asante and Tigoni but the differences were not significant $(P \leq 0.05)$ and the virus titres were very low. None of the plants inoculated with $\mathrm{PVYO}$ developed leaf wrinkle symptoms but those inoculated with PVYN-Wi were found with mosaic and leaf wrinkle symptoms, particularly for cultivars Kenya Mpya and Dutch Robyjn (ranked as $4=$ severe) as compared to those inoculated with $\mathrm{PVY}^{\mathrm{O}}$ (ranked as $2=$ moderately mild).

Table 2 Comparison of severity of PVY symptoms and ELISA OD value in Kenyan potato cultivars inoculated in a screenhouse with $\mathrm{PVY}^{\mathrm{N}-\mathrm{Wi}}$ and $\mathrm{PVYO}$

\begin{tabular}{|c|c|c|c|c|c|c|c|c|}
\hline \multirow[t]{2}{*}{ Cultivar } & \multicolumn{2}{|c|}{ ELISA OD values } & \multicolumn{2}{|l|}{ Infection } & \multicolumn{2}{|c|}{ Symptom score } & \multicolumn{2}{|l|}{ Symptoms } \\
\hline & PVYN-Wi & PVYO & $P V Y^{N-W i}$ & PVYO & PVYN-Wi & PVYO & PVYN-Wi & $\mathrm{PVYO}^{\mathrm{O}}$ \\
\hline Kenya Karibu & $0.052^{\mathrm{ns}}$ & 0.051 & - & - & 0 & 0 & None & None \\
\hline Sherekea & $0.056^{\mathrm{ns}}$ & 0.052 & - & - & 0 & 0 & None & None \\
\hline Shangi & $0.104^{\mathrm{ns}}$ & 0.080 & + & - & 0 & 0 & None & None \\
\hline Asante & $0.114^{\mathrm{ns}}$ & 0.091 & + & \pm & 0 & 0 & None & None \\
\hline Tigoni & $0.122^{\mathrm{ns}}$ & 0.096 & + & + & 0 & 0 & None & None \\
\hline Dutch Robyjn & $1.871^{*}$ & 0.719 & + & + & 4 & 2 & $\mathrm{M}$ and $\mathrm{Wr}$ & M \\
\hline Kenya Mpya & $2.038^{*}$ & 0.716 & + & + & 4 & 2 & $\mathrm{M}$ and $\mathrm{Wr}$ & M \\
\hline NC-Tobacco & $0.049^{\text {ns }}$ & 0.051 & - & - & 0 & 0 & None & None \\
\hline PC-Tobacco & $2.537 *$ & 0.734 & + & + & 4 & 2 & $\mathrm{M}, \mathrm{Vn}$ and $\mathrm{Wr}$ & M \\
\hline
\end{tabular}

ns $=$ no significant difference and $*=$ significant difference $(P \leq 0.05)$. Severity of symptoms, $0=$ no symptoms, $1=$ very mild, $2=$ moderately mild, $3=$ moderate, $4=$ severe and $5=$ very severe,$+=P V Y$ detected and $-=$ PVY not detected and $\pm=$ PVY was not detected in all samples tested, $\mathrm{PC}=$ positive control, $\mathrm{NC}=$ negative control, None $=$ no visible symptoms, $\mathrm{M}=$ mosaic, $\mathrm{Wr}=$ wrinkle and $\mathrm{Vn}=$ veinal necrosis 


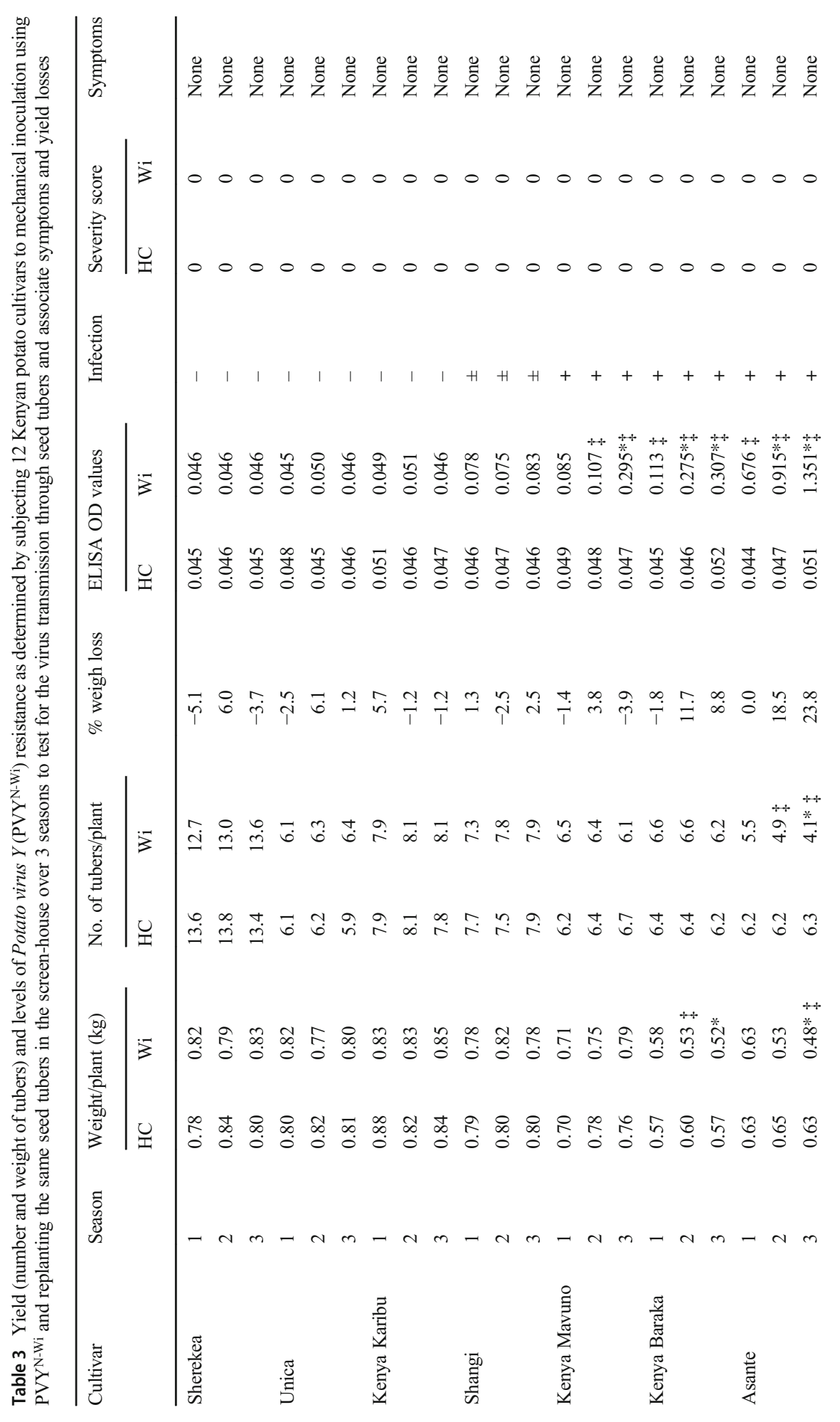




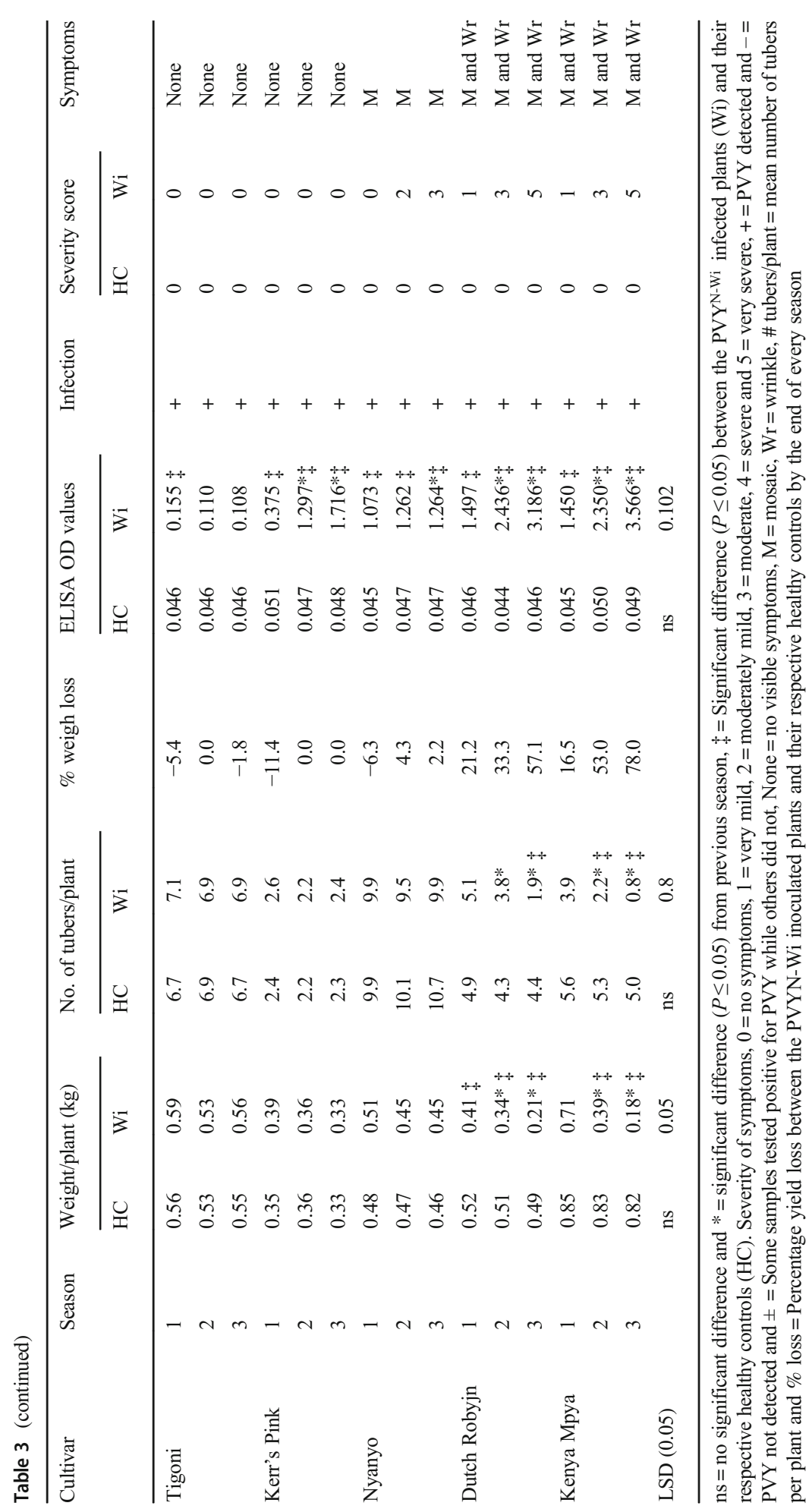




\section{Screening for PVYN-Wi Resistance in a Screen-House over Three Seasons}

Twelve Kenyan potato cultivars were evaluated in a screen-house experiment over three consecutive seasons of replanting tubers. Differences in weight $(\mathrm{kg})$ of tubers, number of tubers per plant, ELISA OD values and severity of symptoms between $\mathrm{PVY}^{\mathrm{N}-W i}$ infected plants and non-infected plants were compared (Table 3). Over the three seasons, PVY ${ }^{\mathrm{N}-\mathrm{Wi}}$ was not detected in the three cultivars Sherekea, Unica and Kenya Karibu. The cultivars were not found with virus symptoms. There was no significant difference $(P \geq 0.05)$ in number and weight of tubers between PVYN-Wi inoculated plants and non-inoculated plants of these cultivars.

Even though Shangi was inoculated with PVYN-Wi, over the seasons ELISA OD values were low to a level that PVY was not detected in some of the samples. There was also no significant $(P \geq 0.05)$ decrease in the weight and number of tubers of PVYN-Wi inoculated plants of this cultivar. Virus symptoms were not observed in this cultivar over the three seasons.

PVYN-Wi infection in cultivars Kenya Mavuno, Kenya Baraka, Asante, Tigoni and Kerr's Pink were symptomless. Among these cultivars, PVYN-Wi infection caused yield losses in cultivar Asante (18.5 and $23.8 \%$ by the end of second and the third season, respectively) and also a reduction in the average number of tubers per plant from 4.9 to 4.1 in comparison with healthy controls. In Kenya Baraka, there was a yield loss of $11.7 \%$ but only by the end of the second season.

There was a significant $(P \leq 0.05)$ increase in the ELISA OD values coupled with a corresponding decrease in weight and number of tubers over the three seasons in cultivars Dutch Robyjn and Kenya Mpya. Characteristic PVYN-Wi symptoms observed in these two cultivars under the screen-house conditions were basically mosaic and wrinkle on the leaves. Severity of the symptoms increased from very mild during the first season to moderate (Fig. 1) in the second season to very severe during the third season. PVYN-Wi infection contributed to a yield loss of 21.2, 33.3 and $57.1 \%$ in Dutch Robyjn and 16.5, 53.6 and 78.0\% in Kenya Mpya by the end of the first, second and third seasons, respectively, when compared to non-inoculated plants. Even though Nyayo was infected and had increasing ELISA OD values and symptom

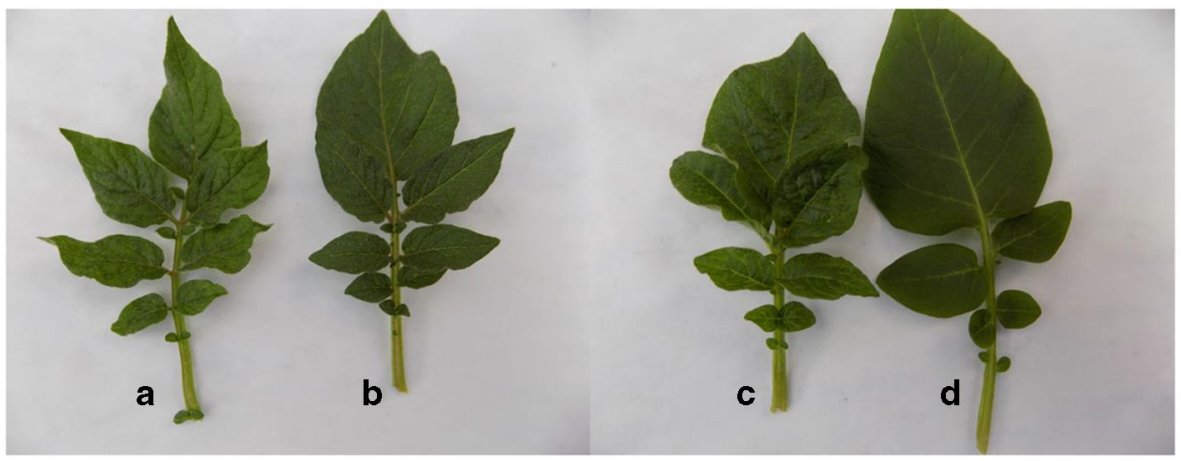

Fig. 1 Leaf symptoms of two PVY susceptible potato cultivars upon inoculation with PVYN-Wi, $\mathbf{a}=$ Cultivar Dutch Robyjn with moderate mosaic and wrinkle, $\mathbf{b}=$ Dutch Robyjn not inoculated (healthy control), $\mathbf{c}=$ Cultivar Kenya Mpya with moderate mosaic and wrinkle and $\mathbf{d}=$ Kenya Mpya not inoculated (healthy control) 
Table 4 Yield loss and Potato virus $Y$ infections in 12 cultivars planted in the field over three consecutive seasons after inoculation with the virus

\begin{tabular}{|c|c|c|c|c|c|c|c|c|}
\hline Cultivar & Season & $\begin{array}{l}\text { ELISA } \\
\text { OD } \\
\text { value }\end{array}$ & Infection & $\begin{array}{l}\text { No.of } \\
\text { tubers/ } \\
\text { plant }\end{array}$ & $\begin{array}{l}\text { Yield } \\
(\mathrm{t} / \mathrm{ha})\end{array}$ & $\begin{array}{l}\% \text { yield } \\
\text { loss }\end{array}$ & $\begin{array}{l}\text { Severity } \\
\text { symptom } \\
\text { score }\end{array}$ & Symptoms \\
\hline \multirow[t]{3}{*}{ Sherekea } & 1 & 0.046 & - & 14.5 & 36.8 & & 0 & None \\
\hline & 2 & 0.045 & - & 13.0 & 36.7 & & 0 & None \\
\hline & 3 & 0.045 & - & 13.7 & 37.3 & -1.4 & 0 & None \\
\hline \multirow[t]{3}{*}{ Kenya Karibu } & 1 & 0.050 & - & 7.5 & 26.0 & & 0 & None \\
\hline & 2 & 0.047 & - & 8.8 & 27.5 & & 0 & None \\
\hline & 3 & 0.048 & - & 8.2 & 25.9 & 0.4 & 0 & None \\
\hline \multirow[t]{3}{*}{ Tigoni } & 1 & 0.148 & + & 9.2 & 29.1 & & 0 & None \\
\hline & 2 & 0.146 & + & 9.1 & 31.4 & & 0 & None \\
\hline & 3 & 0.141 & + & 9.5 & 28.7 & 1.4 & 0 & None \\
\hline \multirow[t]{3}{*}{ Unica } & 1 & 0.047 & - & 7.1 & 35.8 & & 0 & None \\
\hline & 2 & 0.048 & - & 6.8 & 33.9 & & 0 & None \\
\hline & 3 & 0.047 & - & 7.7 & 35.1 & 2.0 & 0 & None \\
\hline \multirow[t]{3}{*}{ Shangi } & 1 & 0.121 & + & 8.9 & 35.6 & & 0 & None \\
\hline & 2 & 0.113 & + & 9.3 & 34.2 & & 0 & None \\
\hline & 3 & 0.141 & + & 8.4 & 34.7 & 2.5 & 0 & None \\
\hline \multirow{3}{*}{$\begin{array}{l}\text { Kenya } \\
\text { Mavuno }\end{array}$} & 1 & 0.049 & - & 6.5 & 21.8 & & 0 & None \\
\hline & 2 & 0.047 & - & 6.5 & 21.2 & & 0 & None \\
\hline & 3 & 0.044 & - & 6.6 & 20.8 & 4.6 & 0 & None \\
\hline \multirow[t]{3}{*}{ Kerr's pink } & 1 & 0.110 & + & 3.7 & 17.4 & & 0 & None \\
\hline & 2 & 0.224 & + & 3.3 & 17.5 & & 0 & None \\
\hline & 3 & 0.207 & + & 3.0 & 15.6 & 10.3 & 0 & None \\
\hline \multirow[t]{3}{*}{ Kenya Baraka } & 1 & 0.147 & + & 4.9 & 19.4 & & 0 & None \\
\hline & 2 & 0.163 & + & 4.3 & 18.0 & & 0 & None \\
\hline & 3 & 0.190 & + & 4.4 & 17.0 & 12.4 & 0 & None \\
\hline \multirow[t]{3}{*}{ Asante } & 1 & 0.133 & + & 5.5 & 30.3 & & 0 & None \\
\hline & 2 & $0.296^{*}$ & + & 6.5 & $25.7 *$ & & 0 & None \\
\hline & 3 & $0.387^{*}$ & + & 7.3 & $26.1 *$ & 13.9 & 0 & None \\
\hline \multirow[t]{3}{*}{ Dutch Robyjn } & 1 & 0.118 & + & 7.3 & 27.8 & & 0 & M \\
\hline & 2 & $0.588^{*}$ & + & 5.6 & 23.6 & & 1 & $\mathrm{M}$ \\
\hline & 3 & $1.487^{*}$ & + & 6.3 & $21.8 *$ & 21.6 & 2 & $\begin{array}{l}\mathrm{Cr}, \mathrm{St}, \mathrm{M} \text {, } \\
\mathrm{Nec}\end{array}$ \\
\hline \multirow[t]{3}{*}{ Nyanyo } & 1 & 0.163 & + & 10.6 & 23.6 & & 1 & M \\
\hline & 2 & $1.108^{*}$ & + & 9.6 & $17.1 *$ & & 2 & M \\
\hline & 3 & $2.017^{*}$ & + & $7.3^{*}$ & $14.4 *$ & 39.0 & 3 & M \\
\hline \multirow[t]{3}{*}{ Kenya Mpya } & 1 & 0.408 & + & 4.6 & 39.2 & & 1 & mosaic \\
\hline & 2 & $1.032 *$ & + & 4.5 & $27.6^{*}$ & & 2 & mosaic \\
\hline & 3 & $1.507 *$ & + & $3.1^{*}$ & $18.4 *$ & 53.1 & 3 & $\begin{array}{l}\mathrm{Cr}, \mathrm{St}, \mathrm{M} \text {, } \\
\quad \mathrm{Nec}\end{array}$ \\
\hline LSD (0.05) & & 0.15 & & 1.4 & 3.8 & & & \\
\hline
\end{tabular}

$\mathrm{Cr}=$ crinkle, $\mathrm{M}=$ mosaic, $\mathrm{St}=$ stunted, healthy $=$ no visible symptoms and $\mathrm{Nec}=$ necrotic symptoms, severity of symptoms score, $0=$ no symptoms, $1=$ very mild, $2=$ moderately mild, $3=$ moderate, $4=$ severe and $5=$ very severe, $+=$ PVY detected and $-=$ PVY not detected and $*=$ Significant difference $(P \leq 0.05)$ with the previous season by mechanical inoculation of virus free potato plants followed by an ELISA test at 28 days post-inoculation 
severity over seasons, there was no significant yield loss in this cultivar over the seasons. None of the tubers harvested for the 12 cultivars showed symptoms of tuber necrotic ring spot diseases (PTNRD) over the three consecutive seasons.

\section{Screening for PVYN-Wi Resistance in the Field over Three Seasons}

In the first season, in vitro plantlets were inoculated with $\mathrm{PVY} \mathrm{Y}^{\mathrm{N}}{ }^{\mathrm{i}}$ strain and the potato plants were maintained in the screen-house. At harvest, at least 120 tubers were randomly picked from each lot of 12 cultivars, sprouted and used to plant the first season field experiment. Tubers harvested from each cultivar were thoroughly mixed and selected randomly and used to plant the second season trial and similarly tubers of the second season trial were used to plant a third season trial. Over the three seasons, the same experimental arrangement, management, data collection and ELISA tests were followed.

The results of the ELISA tests, types of symptoms and severity of symptom at 45 days after planting and number and weight of tubes harvested are summarized in Table 4. PVY was not detected in four cultivars (Unica, Sherekea, Kenya Karibu and Kenya Mavuno). There were no significant $(P \geq 0.05)$ reductions in their number of tubers per plant and yield of tubers ( $t /$ ha) over the three seasons. No PVY symptoms were noted in any of the plants in the plots with these cultivars. Two of these cultivars, Sherekea $(37.3 \mathrm{t} / \mathrm{ha})$ and Unica $(35.1 \mathrm{t} / \mathrm{ha})$, were found with significantly $(P \leq 0.05)$ higher yields than the rest of the cultivars by the end of the third season.

PVY infection did not cause yield losses over the three seasons in cultivars Tigoni, Shangi and Kenya Baraka. In these cultivars, PVY infection was found with very low titres and the plants showed no PVY symptoms. Symptomless PVY infections were also observed in cultivar Asante which showed increasing ELISA OD values and correspondingly significant $(P \leq 0.05)$ yield loss of $13.9 \%$ by the end of the third season.

PVY symptoms were found only in three cultivars, Nyayo, Kenya Mpya and Dutch Robyjn. The characteristic PVY symptoms in Dutch Robyjn and Kenya Mpya were mosaic during the first and the second seasons and mosaic, crinkled leaves, stunted growth and leaf necrosis spreading to the stems in the third season (Fig. 2). Leaf mosaic

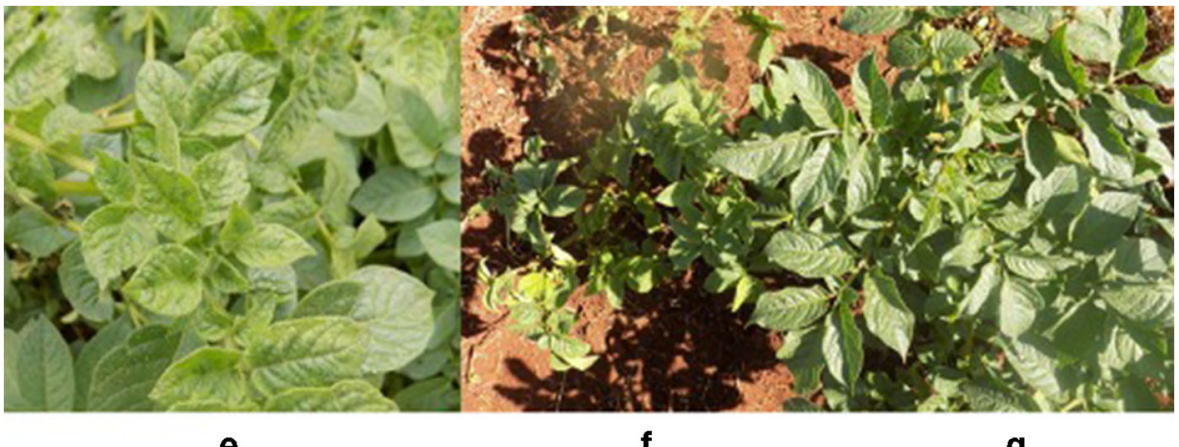

e

$\mathbf{f}$

g

Fig. 2 Characteristic field symptoms of potato virus $\mathrm{Y}(\mathrm{PVY}-\mathrm{Wi})$ in cultivars Dutch Robyjn and Nyayo, $\mathbf{e}=$ Nyayo is showing mosaic symptoms, $\mathbf{f}=$ Dutch Robyjn with stunted growth, mosaic and crinkled leaves observed during the third season of evaluation and $\mathbf{g}=$ Dutch Robyjn without PVYN-Wi infection 
was the only PVY symptom observed in cultivar Nyayo (Fig. 2). The increase in symptom severity over the seasons was coupled to an increase in ELISA OD values and a corresponding reduction in the number and weight of tubers per plant. Percentage yield loss was calculated from the difference in the weight of tubers per plant between the first and the third seasons. There were significant $(P \leq 0.05)$ yield losses of $21.6 \%$ in Dutch Robyjn, 39.0\% in Nyayo and 53.1\% in Kenya Mpya. As a result, the yields were lowest in Nyayo, Kenya Mpya and Dutch Robyjn with 14.4 t/ha, 18.4 t/ha and 21.8 t/ ha, respectively, by the end of the third season.

\section{Screening for PVYN-Wi Resistance in Early Generation Potato Clones}

Sixteen early generation potato clones obtained from the breeding programme of CIP were subjected to sap inoculation with PVYN-Wi. ELISA test results and symptoms observed on leaf samples at 28 DAI were used to identify genotypes with resistance to this PVY strain (Table 5). Two clones (CIP312284.737 and CIP313028.42) were considered to be resistant to PVYN-Wi because they were found free of PVY in ELISA and they also did not show any symptoms at this time point. PVYN-Wi

Table 5 Screening for potato virus $\mathrm{Y}\left(\mathrm{PVY}^{\mathrm{N}-\mathrm{Wi}}\right)$ resistance in early generation International Potato Center (CIP) potato clones where $\mathrm{M}=$ mosaic, severity of symptoms score, $0=$ no symptoms, $1=$ very mild, $2=$ moderately mild, $3=$ moderate, $4=$ severe and $5=$ very severe,$+=$ PVY detected and $-=$ PVY not detected

\begin{tabular}{lllll}
\hline Cultivar/clone & ELISA OD values & Infection & Symptom score & Symptoms \\
\hline CIP312284.737 & 0.046 & - & 0 & None \\
Sherekea & 0.046 & - & 0 & None \\
CIP313028.42 & 0.047 & - & 0 & None \\
Kenya Mpya-NC & 0.047 & - & 0 & None \\
Sherekea-NC & 0.048 & - & 0 & None \\
Dutch Robyjn-NC & 0.049 & - & 0 & None \\
CIP313011.28 & 0.117 & + & 0 & None \\
CIP313009.46 & 0.136 & + & 0 & None \\
CIP314398.114 & 0.224 & + & 0 & None \\
CIP314930.72 & 0.254 & + & 0 & None \\
CIP314923.69 & 0.518 & + & 0 & None \\
CIP312086.768 & 0.564 & + & 1 & $\mathrm{M}$ \\
CIP314921.104 & 0.647 & + & 1 & $\mathrm{M}$ \\
CIP313001.279 & 0.657 & + & 1 & $\mathrm{M}$ \\
CIP313010.19 & 0.668 & + & 1 & $\mathrm{M}$ \\
CIP313002.4 & 0.672 & + & 1 & $\mathrm{M}$ \\
CIP313039.199 & 0.788 & + & 2 & $\mathrm{M}$ \\
CIP313009.84 & 0.801 & + & 2 & $\mathrm{M}$ \\
CIP312084.731 & 0.897 & + & 2 & $\mathrm{M}$ \\
CIP313009.43 & 0.933 & + & 2 & $\mathrm{M}$ \\
Dutch Robyjn & 1.046 & + & 2 & $\mathrm{M}$ \\
Kenya Mpya & 1.075 & 2 & $\mathrm{M}$ \\
\hline & & + & &
\end{tabular}


infected plants of CIP313011.28, CIP313009.46, CIP314398.114, CIP314930.72 and CIP314923.69 were symptomless while the rest of the clones produced mild mosaic symptoms upon infection with PVYN-Wi.

\section{Discussions and Conclusions}

There is evidence that PVY was a problem in the Kenyan potato production system as early as the 1940's (Bock and Robertson 1976). Surveys indicated that PVY remained a problem with a high prevalence of 77.6\% (Gildemacher et al. 2009), 70.0\% (Muthomi et al. 2009) and 27.0\% (Nyamwamu et al. 2014) in the major potato growing areas. In a recent survey for PVY strains in Kenya, $\mathrm{PVY}^{\mathrm{N}-W \mathrm{~W}}$ was found to be the most prevalent PVY strain in cultivars grown in the major potato growing counties (Onditi 2020). In different countries and continents in the world, there are reports of variations in the prevalence rates of the different PVY strains which have also been changing over time with PVYN-Wi and PVYNTN now being most widespread. These changes and differences in PVY strain populations need to be incorporated in setting local breeding objectives by giving greater priority to the most prevalent PVY strains and to the strains causing greater yield losses. The resistance screening in this study was therefore mainly based on this survey by utilizing PVY ${ }^{\mathrm{N}-W i}$ to screen for PVY resistance in Kenyan potato cultivars.

Double antibody sandwich (DAS)-ELISA used in this study is a sensitive serological technique commonly used for routine PVY detection (and other potato viruses) (Solomon-Blackburn and Barker 2001). However, care needs to be taken in setting up the resistance screening experiments to avoid variations that may occur in comparing OD values from one plate to another or from one cropping season to another. In the first experiment where we set out to compare $\mathrm{PVY}{ }^{\mathrm{N}-W i}$ and $\mathrm{PVY}^{\mathrm{O}}$ in their ability to infect and cause disease in local cultivars, we addressed this challenge by designing the experiment to fit one ELISA plate with 96 wells $(7$ genotypes $\times 3$ replications $\times 2$ virus treatments $\times 2$ composites tested per plot $=84$ wells). In the subsequent experiments, our main focus was to use ELISA for detection with the aim to identify cultivars which could not get infected by PVY over the three seasons of replanting virus inoculated potato plants.

We used ELISA OD each year to determine the infection status (positive or negative) for PVY and compared those results across the three seasons. ELISA results across seasons for the different potato cultivars were consistent with the severity of symptoms observed as well as with the weights and numbers of tubers per plant (Table 3).

Tuber numbers increased over seasons, depending on the rate of tuber multiplication per cultivar per season, while the number of tubers selected for planting subsequent seasons remained the same. This means that the proportion of tubers sampled for ELISA testing reduced over seasons. To better achieve this objective, future experiments should ensure that number of samples tested over seasons should increase according to the rate of tuber multiplication of each cultivar per season. However, for this study we only intended to identify cultivars which could not get infected with PVY over there consecutive seasons under natural conditions. 
In the first experiment, PVY ${ }^{\mathrm{N}-W i}$ demonstrated greater pathogenicity in the Kenyan potato cultivars than PVYO In susceptible cultivars, Dutch Robyjn and Kenya Mpya, inoculation of PVYN-Wi caused significantly higher ELISA OD values as compared to $\mathrm{PVY}^{\mathrm{O}}$. This relative higher ability of $\mathrm{PVY}^{\mathrm{N}-W i}$ to cause diseases in Kenyan potato cultivars could be among the factors supporting its spread within the Kenyan potato cultivars. In a recent survey conducted in the major potato growing areas in Kenya, PVYN-Wi was more widely distributed in different regions than PVYO (Onditi 2020). There is therefore a need to identify cultivars with resistance to PVY ${ }^{\mathrm{N}-W i}$ strain.

In this study, PVY infection occurred symptomless in some of the most commonly grown cultivars. Previous studies indicated that such symptomless infections are one of the factors that have contributed to the rapid spread of PVYN-Wi in different potato growing regions all over the world by invisibly acting as a source of PVY inoculum (Karasev and Gray 2013; MacKenzie et al. 2018). Symptomless PVY infections were found in cultivars Shangi, Tigoni, Kerr's Pink, Kenya Baraka and Asante both in the screen-house and in the field screening of cultivars over seasons after inoculation with the PVY strain. These are among the major cultivars grown by the Kenyan farmers. Shangi in particular is grown by the majority $(60.5 \%)$ of farmers (Onditi 2020). Symptomless virus infections can be managed by conducting regular virus surveys to know the regions and cultivars infected with the virus and by replacing susceptible cultivars with resistant ones. In susceptible cultivars with clear symptoms like Dutch Robyjn, Kenya Mpya and Nyayo, PVY can be controlled alternatively by rogueing out symptomatic plants to avoid further spread of the virus or by positive selection i.e. selecting healthy looking plants as planting materials for the subsequent seasons to reduce virus prevalence and subsequently improve potato tubers yields (Gildemacher et al. 2011; Schulte-Geldermann et al. 2012; Priegnitz et al. 2019). In a recent survey, Kenyan farmers were found with limited knowledge of the concept of viruses and virus control and they engage in practices that promote potato virus transmission (Onditi 2020). Most important among these was the practice of replanting virus infected tubers over seasons. This practice contributes to the spread of the viruses from the mother tuber to the daughter tuber from one generation to another (Chandla et al. 2001). Yield losses observed in susceptible cultivars Dutch Robyjn (21.6\%), Nyayo (39.0\%) and Kenya Mpya (53.1\%) were found in cultivars where there was spread of the PVY strain from one season to another through seed tubers (significant increase in ELISA OD values and in symptom severity over seasons).

This study intended to contribute to virus control by identifying locally grown cultivars with PVY resistance which can be recommended to farmers to minimize virus spread. The following criteria were used to identify resistant cultivars:

1. Cultivars that do not get PVY infection at all after sap inoculation with the virus (Solomon-Blackburn and Barker 2001)

2. Cultivars which do not pass PVY infection from one season to another through tubers (Beemster 1976; Dupuis 2017)

3. Cultivars which do not experience significant yield loss after inoculations when evaluated both in the screen-house and in the field over seasons (Solomon-Blackburn and Barker 2001; Rahman et al. 2010) 
Among the 12 cultivars evaluated, the three cultivars Kenya Karibu, Sherekea and Unica were found resistant to PVY because they met all the above criteria. Since these potato cultivars were inoculated with PVY and were evaluated as secondarily infected tubers planted over the three seasons, the results obtained in this study are an indication that it was not possible for PVY to be transmitted through tubers in these cultivars. Considering the Kenyan potato cultivation situation where over $95 \%$ of farmers replant their own non-certified seed tubers and do not have access to certified seed tubers (NPCK 2017), such cultivars can help to control the spread of the virus through seed tubers and can be useful in minimizing virus prevalence in the farmers' fields and subsequent yield losses currently being experienced by the Kenyan farmers. The high yields of $37.3 \mathrm{t} / \mathrm{ha}$ and $35.0 \mathrm{t} / \mathrm{ha}$ in Unica and Sherekea, respectively, are a further indication that these cultivars can be used to improve the low average tubers yields currently reported to be only $8.7 \mathrm{t} /$ ha among the Kenyan farmers' fields.

The second category of cultivars (Tigoni, Shangi, Kerr's Pink and Kenya Baraka) did not experience any significant yield loss over three seasons and though they were PVY infected, there was no significant increase in severity of virus infections over seasons in both screen-house and in the field. These cultivars too can be useful in minimizing virus prevalence, particularly Shangi which is already being grown by the majority $(60.5 \%)$ of the Kenyan farmers and was found with very low (1.4\%) virus prevalence in field surveys conducted in five major potato growing counties in Kenya (Onditi 2020). These cultivars identified with PVY resistance should however be evaluated further to confirm if they also carry other important traits like resistance to late blight and bacterial wilt (Ralstonia solanacearum), large size tubers, good cooking and culinary qualities, market demand (including tuber skin colour), good storability, short dormancy and early maturity to ensure they fit the needs of the whole Kenyan potato value chain in order to be widely adopted (Crissman et al. 1993; Kaguongo et al. 2008).

Future breeding efforts in Kenya should focus on introducing and screening new PVY resistant genotypes with effective resistance genes tested using Kenyan PVY isolates. The identified PVY resistant cultivars can therefore be crossed with local cultivars to introduce the PVY resistance trait. In this study, we made efforts towards this by screening 16 early generation potato genotypes, two of which we identified as PVY resistant as per the ELISA test results at 28 DPI. The clones should be further screened over subsequent seasons of replanting the tubers to confirm resistance under field conditions and to ascertain that these cultivars can reduce PVY transmission through seed tubers over seasons. The clones were generated from crosses made between local Kenyan cultivars and PVY resistant CIP clones with the aim to give a breeding population with both PVY resistance and locally important traits. Unfortunately, it is not known which PVY strain was used in the initial evaluation of their virus resistance. The clones should be further evaluated for other locally important traits and released to benefit the farmers. Further research however would be advisable to genotype the cultivars and identify the specific resistance genes in these cultivars and to relate their mechanism of host resistance with the data obtained in this study.

Acknowledgements We sincerely thank all those who directly or indirectly assisted in the process of this study both from Wageningen University and Research (WUR) the Netherlands and at the Kenya Agricultural and Livestock Research Organization (KALRO), Kenya. We thank KALRO for the financial, physical and 
logistical support during this study. Sincere thanks to Kevin Waweru at KALRO Tigoni for helping in managing the experiments.

Open Access This article is licensed under a Creative Commons Attribution 4.0 International License, which permits use, sharing, adaptation, distribution and reproduction in any medium or format, as long as you give appropriate credit to the original author(s) and the source, provide a link to the Creative Commons licence, and indicate if changes were made. The images or other third party material in this article are included in the article's Creative Commons licence, unless indicated otherwise in a credit line to the material. If material is not included in the article's Creative Commons licence and your intended use is not permitted by statutory regulation or exceeds the permitted use, you will need to obtain permission directly from the copyright holder. To view a copy of this licence, visit http://creativecommons.org/licenses/by/4.0/.

\section{References}

Adams MJ, Zerbini FM, French R, Rabenstein F, Stenger DC, Valkonen JPT (2012) Family Potyviridae. In: King A, Adams M, Carstens E, Lefkowitz E (eds) In virus taxonomy. Ninth report of the international committee on taxonomy of viruses. Elsevier, Oxford, pp 1069-1089

Beemster ABR (1976) Translocation of the potato viruses $\mathrm{Y}^{\mathrm{N}}$ and $\mathrm{Y}^{\mathrm{O}}$ in some potato varieties. Potato Res 19: 169-172. https://doi.org/10.1007/BF02360420

Birch PR, Bryan GJ, Fenton B, Gilroy EM, Hein I, Jones JT, Prashar A, Taylor MA, Torrance L, Toth IK (2012) Crops that feed the world 8: potato: are the trends of increased global production sustainable? Food Sec 4:477-508. https://doi.org/10.1007/s12571-012-0220-1

Bock RK, Robertson DG (1976) Notes on east African plant viruses 9: potato virus Y. E Afr Agric For J 41(4):340-343. https://doi.org/10.1080/00128325.1976.11662819

Chandla VK, Shiv K, Sighn MN, Verma KD, Paul Khurana SM (2001) Role of aphids in degeneration of seed stocks in the higher hills. Ind Pot Ass 28(1):117-118

CIP (2019) Catalogue of advanced clones. International Potato Center, Lima https://research.cip.cgiar.org/ cipcatlg_ac/. Accessed October 2019

Cockerham G (1943) Potato breeding for virus resistance. Ann Appl Biol 30:105-108. https://doi.org/10. 1111/j.1744-7348.1943.tb06166.x

Crissman CC, Crissman LM, Carli C (1993) Seed potato systems in Kenya: a case study. International Potato Center, Lima

Crosslin JM, Hamm PB, Hane DC, Jaeger J, Brown CR, Shiel PJ, Berger PH, Thornton RE (2006) The occurrence of $\mathrm{PVY}, \mathrm{PVY}^{\mathrm{N}}$, and $\mathrm{PVY} \mathrm{N}^{\mathrm{N}} \mathrm{O}$ strains of potato virus $\mathrm{Y}$ in certified potato seed lot trials in Washington and Oregon. Plant Dis 90:1102-1105. https://doi.org/10.1094/PD-90-1102

Dupuis B (2017) The movement of potato virus Y (PVY) in the vascular system of potato plants. Eur J Plant Pathol 147:365-373. https://doi.org/10.1007/s10658-016-1008-5

FAOSTAT (2017) FAOSTAT. Commodities by country, Kenya, potatoes, 2017. http://www.fao.org/faostat/ en/\#rankings/commodities_by_country.

German TL (2001) Potato virus Y. In: Stevenson WR, Loria R, Franc GD, Weingartner DP (eds) Compendium of potato diseases, 2nd edn. The American Phytopathological Society Press, Minnesota, pp 69-71

Gildemacher P, Demo P, Barker I, Kaguongo W, Woldegiorgis G, Wagoire W, Wakahiu M, Leeuwis C, Struik PC (2009) A description of seed potato systems in Kenya, Uganda and Ethiopia. Am J Potato Res 86:373-382. https://doi.org/10.1007/s12230-009-9092-0

Gildemacher P, Schulte-Geldermann E, Borus D, Demo P, Kinyae P, Mundia P, Struik PC (2011) Seed potato quality improvement through positive selection by smallholder farmers in Kenya. Potato Res 54:253-266. https://oi.org/10.1007/s11540-011-9190-5

Green KJ, Brown CJ, Gray SM, Karasev AV (2017) Phylogenetic study of recombinant strains of potato virus Y. Virology 507:40-52. https://doi.org/10.1016/j.virol.2017.03.018

Jones RAC (1990) Strain group specific and virus specific hypersensitive reactions to infection with Potyviruses in potato cultivars. Ann Appl Biol 117:93-105. https://doi.org/10.1111/j.1744-7348.1990. tb04198.x 
Kaguongo WP, Gildemacher P, Demo P, Wagoire W, Kinyae P, Andrade J, Forbes G, Fuglie K, Thiele G (2008) Farmer practices and adoption of improved potato varieties in Kenya and Uganda. International Potato Center (CIP), Lima, pp 15-16

Karasev AV, Gray SM (2013) Continuous and emerging challenges of Potato virus Y in potato. Annu Rev Phytopathol 51:571-586. https://doi.org/10.1007/s00705-013-1859-4

Kehoe MA, Jones RAC (2016) Improving potato virus Y strain nomenclature: lessons from comparing isolates obtained over a 73-year period. Plant Pathol 65:322-333. https://doi.org/10.1111/ppa.12404

Kerlan C, Tribodet M, Glais L, Guillet M (1999) Variability of potato virus Y in potato crops in France. J Phytopathol 147:643-651. https://doi.org/10.1046/j.1439-0434.1999.00441.x

Kopp A, Kondrák M, Bánfalvi Z (2015) Review article: molecular mechanisms of resistance toandin potato. Acta Phytopathologica et Entomologica Hungarica 50(2):151-160

Lorenzen JH, Piche LM, Gudmestad NC, Meacham T, Shiel P (2006) A multiplex PCR assay to characterize potato virus $\mathrm{Y}$ isolates and identify strain mixtures. Plant Dis 90:935-940. https://doi.org/10.1094/PD-900935

Lung'aho C, Lemaga B, Nyongesa M, Gildermacher P, Kinyae P, Demo P, Kabira J (2007) Commercial seed potato production in eastern and Central Africa. Kenya Agricultural Research Institute, Nairobi, pp 132137

MacKenzie TDB, Lavoie J, Nie X, Singh M (2018) Differential spread of potato virus Y (PVY) strains O, N:O and NTN in the field: implications for the rise of recombinant PVY strains in New Brunswick, Canada. Am J Potato Res 95:301-310. https://doi.org/10.1007/s12230-018-9632-6

MoALF (2016) The National Potato Strategy 2016-2020. Ministry of Agriculture Livestock and Fisheries, Nairobi

Munoz RJ, Plaisted RL, Thurston HD (1975) Resistance to potato virus Y in Solanum tuberosum ssp. andigena. Am Potato J 52:107-115. https://doi.org/10.1007/BF02852043

Muthomi JW, Kinyungu TN, Nderitu JH, Olubayo FM (2011) Incidence of aphid-transmitted viruses in farmer-produced seed potato tubers in Kenya. Afr J Hort Sci 5:18-25. https://doi.org/10.3923/ajps.2009. 166.171

Muthomi JW, Nyaga JN, Olubayo FM, Nderitu JH, Kabira JN, Kiretai SM, Aura JA, Wakahiu M (2009) Incidence of aphid transmitted viruses in farmer-based seed potato production in Kenya. Asian J Plant Sci 8(2):166-171. https://doi.org/10.3923/ajps.2009.166.171

NPCK (2017) Potato variety catalogue. National Potato Council of Kenya, Nairobi

Nyamwamu P, Mukoye B, Osogo A, Omuse C, Ajanga S, Were HK (2014) Distribution and biological characterization of potato virus $\mathrm{Y}$ in Kenya. J Agri-Food Appl Sci 2:258-264

Onditi J (2020) Epidemiology and control of potato virus Y in Kenya. PhD thesis. Wageningen University, Netherlands ISBN: 978-94-6395-322-1

Onditi JO, Nderitu SWK, Landeo JA, Abong' GO, Sikinyi EO, Kabira JN (2012) Release of three improved varieties for the expanded potato market in Kenya. Agric Biol J N Am 3(5):192-197. https://doi.org/10. 5251/abjna.2012.3.5.192.197

Priegnitz U, Lommen WJM, van der Vlugt RAA, Struik PC (2019) Impact of positive selection on incidence of different viruses during multiple generations of potato seed tubers in Uganda. Potato Res 62(1):1-30. https://doi.org/10.1007/s11540-018-9394-Z

Quenouille J, Vassilakos N, Moury B (2013) Potato virus Y: a major crop pathogen that has provided major insights into the evolution of viral pathogenicity. Mol Plant Pathol 14:439-452. https://doi.org/10.1111/ mpp. 12024

Rahman MS, Akanda AM, Mian IH, Bhuian MKA, Karim MR (2010) Growth and yield performance of different generations of seed potato as affected by PVY and PLRV. Bangladesh J Agric Res 35:37-39. https://doi.org/10.3329/bjar.v35i1.5865

Sato M, Nishikawa K, Komura K, Hosaka K (2006) Potato virus Y resistance gene, Rychc, mapped to the distal end of potato chromosome 9. Euphytica 149:367-372. https://doi.org/10.1007/s10681-006-9090-y

Scholthof KG, Adkins S, Czosnek H, Palukaitis P, Jaquot E, Hohn T, Hohn B, Saunders K, Candresse T, Ahlquist P, Hemenway C, Foster G (2011) Top 10 plant viruses in molecular plant pathology. Mol Plant Pathol 12:938-954. https://doi.org/10.1111/j.1364-3703.2011.00752.x

Schulte-Geldermann E, Gildemacher PR, Struik PC (2012) Improving seed health and seed performance by positive selection in three Kenyan potato varieties. Am J Potato Res 89:424 429. https://doi.org/10.1007/ s12230-012-9264-1

Singh RP, Valkonen JPT, Gray SM, Boonham N, Jones RAC, Kerlan C, Schubert J (2008) Discussion paper: the naming of potato virus $\mathrm{Y}$ strains infecting potato. Arch Virol 153:1-13. https://doi.org/10.1007/ s00705-007-1059-1 
Solomon-Blackburn RM, Barker H (2001) A review of host major-gene resistance to potato viruses X, Y, a and $\mathrm{V}$ in potato, genes, genetics and mapped locations. Heredity 86:8-16. https://doi.org/10.1046/j.13652540.2001.00798.x

Steel RGD, Torrie JH (1980) Principles and procedures of statistics. A biometrical approach, 2nd edn. McGraw and hill Inc, New York City

Valkonen JPT, Gebhardt C, Zimnoch-Guzowska E, Watanabe KN (2017) Resistance to Potato virus Y in potato. In: Lacomme C, Glais L, Bellstedt D, Dupuis B, Karasev A, Jacquot E (eds) Potato virus Y: biodiversity, pathogenicity, epidemiology and management. Springer, Cham. https://doi.org/10.1007/9783-319-58860-5 8

Were HK, Kabira JN, Kinyua ZM, Olubayo FM, Karinga JK, Aura J, Lees AK, Cowan GH, Torrance L (2013) Occurrence and distribution of potato pests and diseases in Kenya. Potato Res 123:12-25. https:// doi.org/10.1007/s11540-013-9246-9

Publisher's Note Springer Nature remains neutral with regard to jurisdictional claims in published maps and institutional affiliations. 